\title{
The development of descending serotonergic modulation of the spinal nociceptive network: a life span perspective
}

Citation for published version (APA):

de Kort, A. R., Joosten, E. A. J., Patijn, J., Tibboel, D., \& van den Hoogen, N. J. (2022). The development of descending serotonergic modulation of the spinal nociceptive network: a life span perspective. Pediatric Research, 91(6), 1361-1369. https://doi.org/10.1038/s41390-021-01638-9

Document status and date:

Published: 01/05/2022

DOI:

10.1038/s41390-021-01638-9

Document Version:

Publisher's PDF, also known as Version of record

\section{Document license:}

Taverne

\section{Please check the document version of this publication:}

- A submitted manuscript is the version of the article upon submission and before peer-review. There can be important differences between the submitted version and the official published version of record.

People interested in the research are advised to contact the author for the final version of the publication, or visit the DOI to the publisher's website.

- The final author version and the galley proof are versions of the publication after peer review.

- The final published version features the final layout of the paper including the volume, issue and page numbers.

Link to publication

\footnotetext{
General rights rights.

- You may freely distribute the URL identifying the publication in the public portal. please follow below link for the End User Agreement:

www.umlib.nl/taverne-license

Take down policy

If you believe that this document breaches copyright please contact us at:

repository@maastrichtuniversity.nl

providing details and we will investigate your claim.
}

Copyright and moral rights for the publications made accessible in the public portal are retained by the authors and/or other copyright owners and it is a condition of accessing publications that users recognise and abide by the legal requirements associated with these

- Users may download and print one copy of any publication from the public portal for the purpose of private study or research.

- You may not further distribute the material or use it for any profit-making activity or commercial gain

If the publication is distributed under the terms of Article $25 \mathrm{fa}$ of the Dutch Copyright Act, indicated by the "Taverne" license above, 


\title{
The development of descending serotonergic modulation of the spinal nociceptive network: a life span perspective
}

\author{
Anne R. de Kort $\mathbb{D}^{1,2^{凶}}$, Elbert A. J. Joosten ${ }^{1,2}$, Jacob Patijn ${ }^{1,2}$, Dick Tibboel ${ }^{3}$ and Nynke J. van den Hoogen ${ }^{1,2,4}$ \\ (c) The Author(s), under exclusive licence to the International Pediatric Research Foundation, Inc 2021
}

\begin{abstract}
The nociceptive network, responsible for transmission of nociceptive signals that generate the pain experience, is not fully developed at birth. Descending serotonergic modulation of spinal nociception, an important part of the pain network, undergoes substantial postnatal maturation and is suggested to be involved in the altered pain response observed in human newborns. This review summarizes preclinical data of the development of descending serotonergic modulation of the spinal nociceptive network across the life span, providing a comprehensive background to understand human newborn pain experience and treatment. Sprouting of descending serotonergic axons, originating from the rostroventral medulla, as well as changes in receptor function and expression take place in the first postnatal weeks of rodents, corresponding to human neonates in early infancy. Descending serotonergic modulation switches from facilitation in early life to bimodal control in adulthood, masking an already functional 5- $\mathrm{HT}$ inhibitory system at early ages. Specifically the $5-\mathrm{HT}_{3}$ and $5-\mathrm{HT}_{7}$ receptors seem distinctly important for pain facilitation at neonatal and early infancy, while the $5-\mathrm{HT}_{1 \mathrm{a}}, 5-\mathrm{HT}_{1 \mathrm{~b}}$, and $5-\mathrm{HT}_{2}$ receptors mediate inhibitory effects at all ages. Analgesic therapy that considers the neurodevelopmental phase is likely to result in a more targeted treatment of neonatal pain and may improve both short- and long-term effects.
\end{abstract}

Pediatric Research; https://doi.org/10.1038/s41390-021-01638-9

\section{IMPACT:}

- The descending serotonergic system undergoes anatomical changes from birth to early infancy, as its sprouts and descending projections increase and the dorsal horn innervation pattern changes.

- Descending serotonergic modulation from the rostral ventral medulla switches from facilitation in early life via the 5- $\mathrm{HT}_{3}$ and 5$\mathrm{HT}_{7}$ receptors to bimodal control in adulthood.

- A functional inhibitory serotonergic system mainly via $5-\mathrm{HT}_{1 \mathrm{a}}, 5-\mathrm{HT}_{1 \mathrm{~b}}$, and $5-\mathrm{HT}_{2 \mathrm{a}}$ receptors at the spinal level exists already at the neonatal phase but is masked by descending facilitation.

\section{INTRODUCTION}

Pain is a powerful survival signal that can be experienced throughout the whole life span. Nevertheless, due to immaturity of the nociceptive network, the experience of pain and the processing of noxious stimuli differs in the newborn neonate as compared to infancy, childhood, and adulthood. ${ }^{1-5}$ At birth, reflex responses to noxious stimuli are exaggerated and uncoordinated, becoming more refined with increasing age in both human and rodent neonates. ${ }^{2,6,7}$ Discrimination between touch and nociceptive stimuli is also fine-tuned during postnatal development. ${ }^{3,4}$ These changing pain behaviors from birth to adulthood in both human and rodents mirror the maturation of the nociceptive network, responsible for processing of nociceptive signals. Postnatal structural and functional fine-tuning of the nociceptive network is an activitydependent process, requiring input from the environment to finalize. ${ }^{8-10}$ This, however, also leaves this system vulnerable to excessive input in early life, such as neonatal pain. ${ }^{11-13}$ Refinement of neural excitability in the spinal cord dorsal horn, the first and most important level of processing of nociceptive information ${ }^{14}$ (see Box 1), occurs through a variety of neuronal processes, including the emergence of top-down inhibitory modulation of spinal nociception. ${ }^{1,11}$

Preclinical studies in rodents indicate that descending inhibitory modulation of the nociceptive signaling is still immature immediate around birth, especially in preterm newborns, and will switch from facilitation to inhibition during the first 3 postnatal weeks. ${ }^{15-19}$ Notably, the rostral ventral medulla (RVM) is the major source of descending serotonergic modulation of spinal nociception and has been shown to enhance rather than inhibit nociceptive stimuli in early life in rodents. ${ }^{17}$ These descending serotonergic projections and their receptors are targeted for pharmacological treatment of pain in adults due to their expression in the spinal dorsal horn ${ }^{20}$ and could also potentially be utilized to attenuate the acute effects of overstimulation of the

\footnotetext{
${ }^{1}$ Department of Anesthesiology and Pain Management, Maastricht University Medical Centre+, Maastricht, the Netherlands. ${ }^{2}$ Department of Translational Neuroscience, School of Mental Health and Neuroscience, Maastricht University, Maastricht, the Netherlands. ${ }^{3}$ Intensive Care and Department of Pediatric Surgery, Erasmus MC-Sophia Children's Hospital, Rotterdam, the Netherlands. ${ }^{4}$ Department of Comparative Biology and Experimental Medicine, Hotchkiss Brain Institute, University of Calgary, Calgary, AB, Canada. email: r.dekort@maastrichtuniversity.nl
} 
Box 1. Nociception: the role of descending serotonergic RVM-spinal dorsal horn projections

Nociceptive information from peripheral primary afferent $C$ and $A \delta$ fibers, as well as touch information from $A \beta$ fibers, is transmitted to second-order projection neurons in the spinal dorsal horn. ${ }^{124}$ These projection neurons are either nociceptive-specific (NS) neurons in laminae I and II (receives input from C and $A \delta$ fibers) or wide dynamic range (WDR) neurons in laminae $V$ (receives direct or indirect input from all three types of cutaneous afferents $(C, A \delta$, and $A \beta)$ ). Via the spinothalamic pathway, nociceptive information is perceived and integrated in the brain centers, including the prefrontal cortex, somatosensory cortex, and anterior cingulate cortex. ${ }^{124}$ Brainstem centers modulate spinal nociceptive processing via the spino-bulbo-spinal loop. The RVM, which includes the nucleus raphe magnus (NRM) and adjacent reticular formation, is part of this a spino-bulbo-spinal loop that is activated by ascending nociceptive input and drives descending modulation of the spinal dorsal horn. ${ }^{16}$ Serotonergic neurons from the RVM project to laminae $\mathrm{I}$, II, and $\mathrm{V}$ of the spinal dorsal horn where projection neurons reside and are therefore a major source of descending modulation of nociceptive input. $^{14,125}$ Descending serotonergic modulation of nociception is mediated via seven $5-\mathrm{HT}$ receptor families $\left(5-\mathrm{HT}_{1}-5-\mathrm{HT}_{7}\right)$ that comprise 15 receptor subtypes ${ }^{126}$ expressed in the spinal cord and brainstem.

nociceptive system at an early age. The neonatal period is unique in how it processes noxious stimuli and develops differently after aberrant noxious stimulation, leading to changes in pain processing throughout life. ${ }^{11-13}$ In this respect, treatment of pain should be based on the understanding of the neurodevelopment of the nociceptive system. Increased knowledge of the development of descending serotonergic RVM-spinal dorsal horn projections has significant implications for the understanding and subsequent treatment of pain throughout the whole life span. Here we summarize preclinical data of the serotonergic descending modulation of the spinal nociceptive network during postnatal development, highlighting which receptors may be involved in the functionality of the descending serotonergic modulation at various phases throughout life in rodents. This will provide a better understanding of postnatal pain processing that ultimately can identify possible pharmacological pain treatment to improve short- and long-term outcome in the vulnerable population of neonates and children.

The review starts with the newborn rodent, where the developmental phase of the nociceptive network is similar to the developmental phase in human neonates during the second and third semester (see Fig. 1) and therefore representing premature newborns (>25 gestational weeks). ${ }^{21-23}$ The preweaning phase from postnatal day (P) 7 to P21 represents the phase of neuronal development in a human neonate at term birth (40 gestational weeks), and the developmental processes have reached a similar level as seen in human infants at weaning (1-2 years of age). ${ }^{21,22}$ Finally, we discuss descending serotonergic modulation from weaning into adulthood.

\section{SEROTONERGIC DESCENDING MODULATION OF NOCICEPTION DURING THE NEONATAL PHASE (PO-P7) \\ Anatomy of descending serotonergic RVM-spinal dorsal horn projections}

In the RVM, 5-HT-positive neurons emerge as early as embryonic days 13-16 and do not change in absolute number with postnatal age. ${ }^{17,24-26}$ Similarly, the proportion of spinally projecting RVM serotonergic neurons remains stable over the first postnatal week in rodents, corresponding with preterm to term human neonate, and accounts for only $3-10 \%$ of all spinally projecting serotonergic neurons. ${ }^{17,27}$ Even though the proportion of serotonergic RVM neurons projecting to the spinal cord does not change during the first postnatal week, the number of serotonergic axons increases in the dorsal horn as fibers grow and sprout further, and innervation follows a rostral to caudal and ventral to dorsal gradient. ${ }^{17,25,28-30}$ Overall, spinal 5-HT axon innervation maturing from rostral to caudal could indicate serotonergic modulation of the spinal dorsal horn, and therefore sensitivity, develops earlier at the cervical level followed by lower (thoracic and lumbar) levels in neonates. ${ }^{25,28,31}$ The ventral to dorsal gradient ensures that the first serotonergic fibers invade the deeper dorsal horn around birth in rodents, and their innervation increases progressively throughout the cord in the first few postnatal days. ${ }^{25,28,31}$ By P7 (or term human birth), the RVM serotonergic axons project to the entire dorsal horn as they now also reach the upper laminae I and II (substantia gelatinosa) at all spinal cord levels ${ }^{17,25,28-30}$ (see Fig. 2).

\section{Functional implications of descending serotonergic RVM-spinal dorsal horn projections: effects on the nociceptive network}

Facilitation of the dorsal horn nociceptive network. Descending serotonergic projections from the RVM to spinal cord, despite their low presence neonates, facilitate (enhance) both noxious and tactile spinal processing in the dorsal horn, thereby increasing the chance of signal transmission up to the brain via projection neurons. ${ }^{17,18,32}$ This facilitation is observed in a minority of projection neurons in the dorsal horn of 1-week-old pups. ${ }^{33-36}$ Electrophysiological studies using spinal cord slice preparations show that postsynaptic facilitation of dorsal horn responses in the first postnatal week occurs through the $5-\mathrm{HT}_{3}$ and $5-\mathrm{HT}_{7}$ receptors and to a lesser extent via $5-\mathrm{HT}_{2}$ receptor activation (see Fig. $3 \mathrm{a}$ top). ${ }^{33,34,36}$ Spinal 5-HT acts in a biphasic fashion via the presynaptic $5-\mathrm{HT}_{3}$ receptor, enhancing excitability of dorsal horn neurons at low concentrations, while enhancing inhibition at higher concentrations. ${ }^{35-38}$

Inhibition of the dorsal horn nociceptive network. Although descending RVM projections predominantly facilitate spinal somatosensory processing during the first postnatal week (see "Facilitation of the dorsal horn nociceptive network"), endogenous release and/or exogenous application of $5-\mathrm{HT}$ on (isolated) neonatal spinal cord preparations has the potential to produce inhibition at both superficial and deeper dorsal horn levels in 1-week-old animals. ${ }^{33-35,37-39}$ This suggests that inhibitory mechanisms are already present in neonates but are masked by the facilitatory influence from the RVM. Primary afferent-evoked responses are inhibited via presynaptic $5-\mathrm{HT}_{1 \mathrm{a}}$ and $5-\mathrm{HT}_{2 \mathrm{a}}$ receptors in the spinal dorsal horn, thereby reducing the chance of signal transmission to projection neurons in the first postnatal week (see Fig. 3a bottom). ${ }^{35,37-39}$ Postsynaptic dorsal horn responses are inhibited by means of increasing the incidence of long-term depression via postsynaptic $5-\mathrm{HT}_{1 \mathrm{a}^{-}}$and $5-\mathrm{HT}_{1 \mathrm{~b}^{-}}$ mediated binding in neonatal pups (P0-P7) (see Fig. 3a bottom). ${ }^{33-36}$ Blocking the $5-\mathrm{HT} 1_{\mathrm{a}}$ receptors exclusively produces facilitation of the deep dorsal horn responses, ${ }^{33,34}$ suggesting that $5-\mathrm{HT}_{1 \mathrm{a}}$ receptors tonically inhibit evoked responses in the dorsal horn of neonatal pups. ${ }^{33,34}$ The postsynaptic $5-\mathrm{HT}_{2 \mathrm{a}}$ receptor causes modest inhibition of synaptic transmission in deep dorsal horn neurons of P3-P6 pups and is not tonically active in the first postnatal week. ${ }^{33,34}$ Next to direct modulation of primary afferent input or dorsal horn responses, local inhibitory synaptic transmission, mediated via gamma-aminobutyric acid (GABA) and glycine, can also be potentiated by the $5-\mathrm{HT}_{3}$ and $5-\mathrm{HT}_{2 \mathrm{a}}$ receptors in the neonatal spinal cord, indirectly reducing primary afferent input. ${ }^{37}$

\section{Conclusions}

The first descending serotonergic axons, originating in the RVM and projecting to the spinal dorsal horn, emerge during the first postnatal week (P0-P7) and terminate mainly in the deeper but not in the superficial laminae of the dorsal horn. Descending serotonergic RVM projections predominantly facilitate spinal nociceptive processes in neonates via the $5-\mathrm{HT}_{3}$ and $5-\mathrm{HT}_{7}$, and to a lesser extent the $5-\mathrm{HT}_{2}$ receptor-mediated binding, despite 


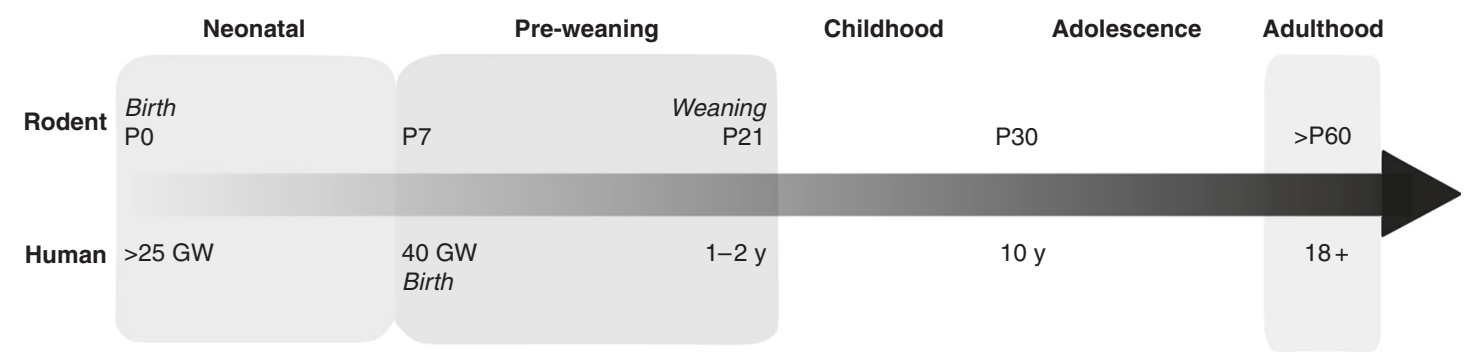

Fig. 1 Developmental timelines for rodents (top) and humans (bottom), illustrating the neonatal, pre-weaning, childhood, adolescent, and adulthood phases. GW gestational weeks, P postnatal day, y years.

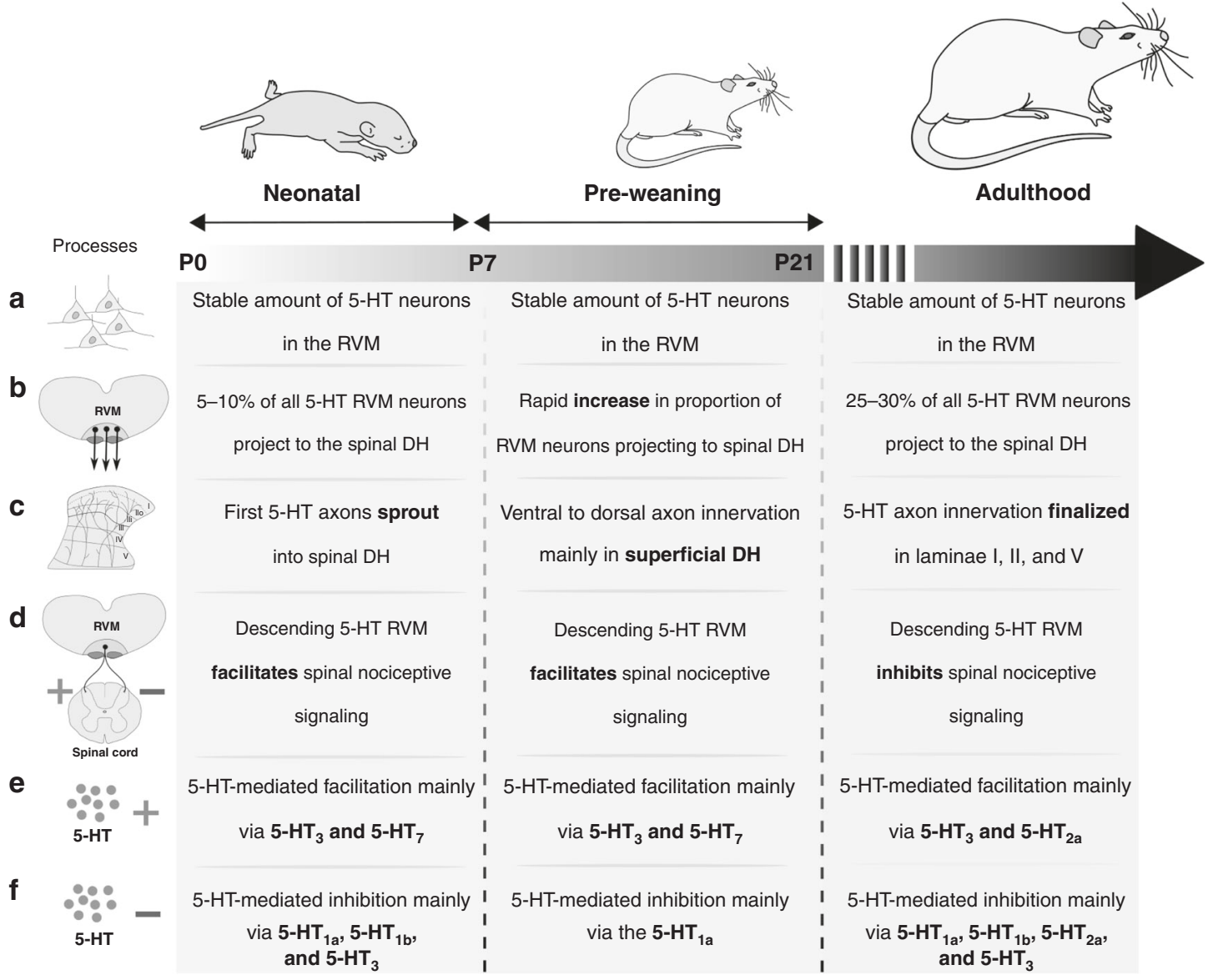

Fig. 2 The development of descending serotonergic modulation of the spinal nociceptive network in neonatal, pre-weaning, and adulthood phases for the following processes. a RVM cell bodies, $\mathbf{b}$ descending serotonergic projections from the RVM to the spinal dorsal horn, c spinal dorsal horn axon innervation over the laminae, $\mathbf{d}$ the overall effect of RVM-spinal dorsal horn serotonergic modulation of nociceptive signaling, e receptors involved in 5-HT-mediated facilitation in the spinal dorsal horn, and f receptors involved in 5-HT-mediated inhibition in the spinal dorsal horn. RVM rostral ventral medulla, DH dorsal horn, 5-HT 5-hydroxytryptamine.

the presence of inhibitory mechanisms via the $5-\mathrm{HT}_{1 \mathrm{a}}, 5-\mathrm{HT}_{1 \mathrm{~b}}$, and $5-\mathrm{HT}_{2}$ receptors.

\section{SEROTONERGIC DESCENDING MODULATION OF NOCICEPTION DURING PRE-WEANING (P7-P21)}

Anatomy of descending serotonergic RVM-spinal dorsal horn projections

During the pre-weaning phase (P7-P21), the descending serotonergic system undergoes substantial anatomical changes (see Fig. 2). Within the RVM, 5-HT-positive neurons show an increased spatial distribution, with an increasing soma diameter and dendritic growth in the second and third postnatal week. ${ }^{40,41}$
However, the absolute number of 5 -HT-positive neurons in the RVM remains unaltered. ${ }^{17,26,27,41,42}$ Most importantly, the amount of descending projections from 5-HT-positive cell bodies in the RVM significantly increases between the first and second week, reaching adult proportions around P14-P16. ${ }^{17,27}$

Following a rapid increase in RVM-spinal cord-projecting neurons between the first and second postnatal week, 5-HT axon terminals increase throughout the spinal cord over the second and third postnatal week. ${ }^{28-31}$ Between P7 and P14, the number of 5-HT axon terminals increases significantly, particularly in laminae I and II where nociceptive-specific (NS) projection neurons reside (see Fig. 2). ${ }^{17,25,28,31}$ By P14, axon innervation evolves from a diffuse network to a more defined pattern, with 5-HT terminals 


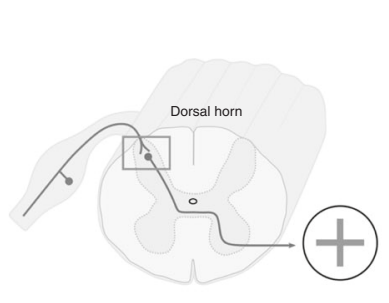

5-HT-mediated facilitation a

Neonatal
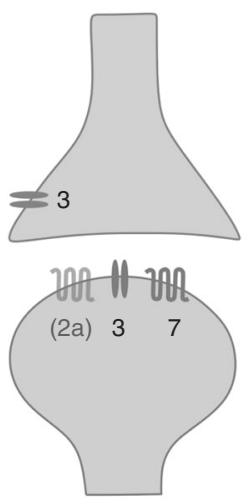

b

Pre-weaning
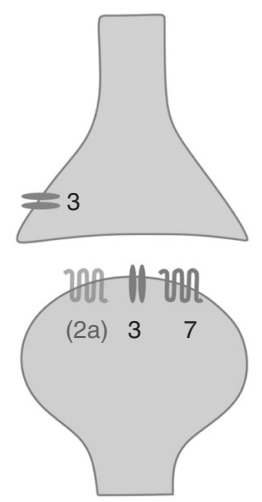

C
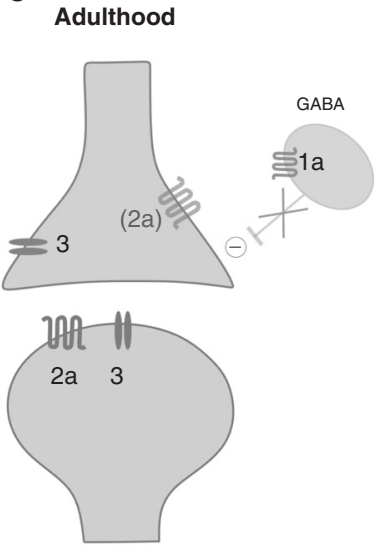

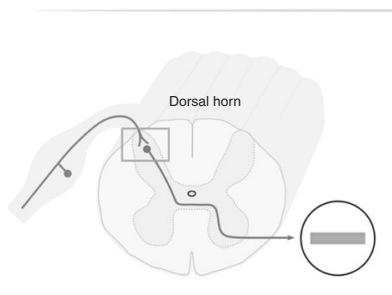

5-HT-mediated inhibition
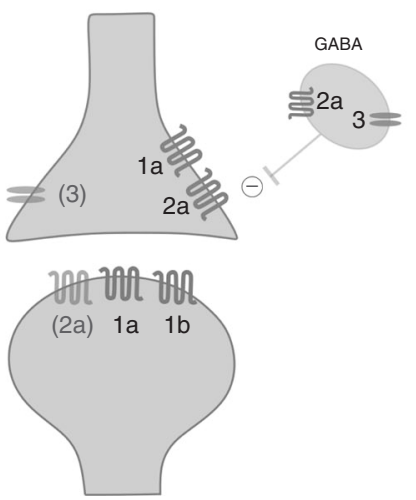
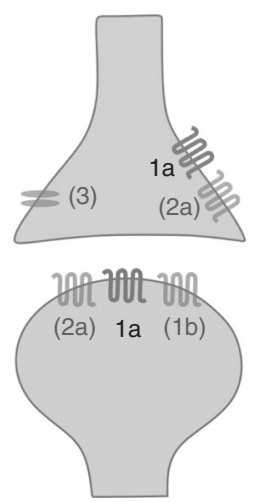
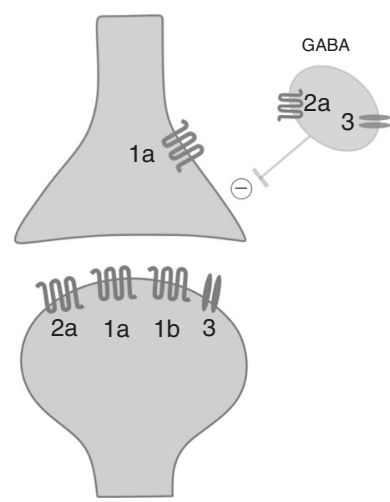

Fig. 3 5-HT receptors involved in 5-HT-mediated facilitation (top) and inhibition (bottom) of the nociceptive network in the dorsal horn in a neonatal, $\mathbf{b}$ pre-weaning, and $\mathbf{c}$ adulthood phases. 5-HT-mediated facilitation (top). In neonates (a) as well as in pre-weanling animals (b), 5- $\mathrm{HT}$ facilitates nociceptive signaling via the presynaptic $5-\mathrm{HT}_{3}$ receptor on primary afferent terminals (in blue) and postsynaptic 5- $\mathrm{HT}$, and $5-\mathrm{HT}_{7}$ receptors (in purple), and to a lesser extent via the 5- $\mathrm{HT}_{2 \mathrm{a}}$ receptor. In adulthood (c), 5- $\mathrm{HT}_{3}$ and $5-\mathrm{HT}_{2 a}$ facilitate both presynaptic and postsynaptic signaling, whereas the $5-\mathrm{HT}_{1 \text { a }}$ directly blocks GABAergic interneurons thereby causing disinhibition of projection neurons and enhancing nociceptive signaling in the dorsal horn. Unlike in younger animals, the $5-\mathrm{HT}_{7}$ does not play a role in serotonin-mediated facilitation in adults. 5-HT-mediated inhibition (bottom). In neonates (a), inhibition of primary afferent-evoked responses (in blue) occurs through the $5-\mathrm{HT}_{1 \mathrm{a}}, 5-\mathrm{HT}_{2 \mathrm{a}}$ and $5-\mathrm{HT}_{3}$ receptors. 5- $\mathrm{HT}$ mediates postsynaptic inhibition through the 5- $\mathrm{HT}_{1 \mathrm{a}}$ and $5-\mathrm{HT}_{1 \mathrm{~b}}$, and to a lesser extent the $5-\mathrm{HT}_{2 \mathrm{a}}$ receptor. Both the 5- $\mathrm{HT}_{2 \mathrm{a}}$ and $5-\mathrm{HT}_{3}$ mediate GABA release of inhibitory interneurons in the spinal dorsal horn. In pre-weanling animals (b), the $5-\mathrm{HT}_{1 \mathrm{a}}$ is mainly responsible for $5-\mathrm{HT}$-induced inhibition. $5-\mathrm{HT}_{1 \mathrm{~b}}, 5-\mathrm{HT}_{2 \mathrm{a}}$ and $5-\mathrm{HT}_{3}$ only show modest inhibition. In adulthood (c), 5- $\mathrm{HT}_{1 \mathrm{a}}$ inhibits nociceptive afferent-evoked responses via presynaptic and postsynaptic mechanisms, whereas the 5- $\mathrm{HT}_{1 \mathrm{~b}}, 5-\mathrm{HT}_{2}$, and 5- $\mathrm{HT}_{3}$ inhibit projection neurons (purple), either directly or by activation of inhibitory GABAergic signaling (green).

only present in superficial and deep dorsal horn laminae and absent in lamina III. $25,28-31$ From P14 to P21, a progressive reinforcement of 5-HT axons and terminals in the spinal dorsal horn occurs, with clear distinction between the densely innervated laminae I and II, an average density in laminae $\mathrm{V}$, and almost no labeling in laminae III-IV. ${ }^{28-31}$ Although density of 5-HT projections appears higher between P7 and P21 compared with adulthood, ${ }^{28}$ quantification of retrograde-labeled neurons from the RVM show similar levels of serotonergic projections to the spinal dorsal horn from $\mathrm{P} 16$ to $\mathrm{P} 30^{17}$ and from P14 to P28. ${ }^{27}$ Possibly, sprouts are increased during pre-weaning followed by a period of pruning that results in an adult pattern of innervation.

\section{Functional implications of descending serotonergic RVM-spinal dorsal horn projections: effects on the nociceptive network}

Facilitation of the dorsal horn nociceptive network. In a similar way as observed in term neonates (P8), descending serotonergic projections from the RVM continue to facilitate both spinal nociceptive and tactile processes at P21 or weaning. ${ }^{17,18,43}$ This enhancement of both tactile and nociceptive stimuli in the dorsal horn is mediated via the $5-\mathrm{HT}_{3}$ receptor. ${ }^{17}$ The increase in descending serotonergic projections during pre-weaning does not (yet) change the directionality of descending 5-HT modulation at P8 versus P21, although weak descending inhibition is first observed around P12. ${ }^{17,43}$ Between P7 and P21, 5-HT-mediated facilitation occurs via the $5-\mathrm{HT}_{2}, 5-\mathrm{HT}_{3}$, and $5-\mathrm{HT}_{7}$ receptor binding (see Fig. 3b top). ${ }^{34,36,44-49}$ Similar to neonates, presynaptic $5-\mathrm{HT}_{3}$ and $5-\mathrm{HT}_{2}$ receptor activation increases the primary afferentevoked responses onto projection neurons in the dorsal horn during pre-weaning. ${ }^{44,47}$ In addition, activation of the $5-\mathrm{HT}_{3}$ and $5-\mathrm{HT}_{7}$ facilitates local postsynaptic dorsal horn responses in P7-P21 pups. ${ }^{17,34,36,44,46}$ Postsynaptic $5-\mathrm{HT}_{2 \mathrm{a}}$ receptor-mediated effects on nociception seem only modest in pre-weanling animals, which was similar to the effect observed in neonates. ${ }^{34}$ The low presence of $5-\mathrm{HT}_{2 a}$ on GABAergic interneurons, together with immature GABAergic signaling in the early postnatal period, might explain the modest inhibitory effects of $5-\mathrm{HT}_{2 \mathrm{a}}$ receptor activation on modulation of nociceptive transmission during development. $^{50-52}$ 
Inhibition of the dorsal horn nociceptive network. Despite a predominantly facilitatory effect from the serotonergic projections originating at the RVM on the spinal dorsal horn nociceptive network, 5-HT applied to the spinal cord is capable of inhibiting primary afferent-evoked responses and postsynaptic responses in the majority of dorsal horn neurons in pre-weanling animals when investigated in isolation. ${ }^{34,36,44,45,47-49,53-55} 5$ - $\mathrm{HT}$ can also inhibit somatosensory input from adjacent dermatomes, thereby reducing the sensory contrast and shaping the receptive field properties of deep dorsal horn projection neurons in laminae IV and $\mathrm{V}$ at P8-P10 ${ }^{53}$. 5-HT-induced inhibition of the dorsal horn nociceptive processing in pre-weanling animals is mediated by the $5-\mathrm{HT}_{1}$ receptor family, specifically the $5-\mathrm{HT}_{1 a}$ receptors both on the presynaptic and postsynaptic side (see Fig. 3b bottom). ${ }^{34,44-46,48,56}$ The $5-\mathrm{HT}_{1 \mathrm{a}}$ receptor is tonically activated during the pre-weaning phase, producing inhibition of nociception similar to that seen in the neonatal phase or first postnatal week. $^{34,44,45}$ In addition, the $5-\mathrm{HT}_{1 \mathrm{a}}$ is involved in thermal- but not mechanical-induced nociception in pre-weanling animals. ${ }^{56}$ Unlike the involvement of $5-\mathrm{HT}_{1 \mathrm{a}}$ in the 5 -HT-mediated inhibition, activation of $5-\mathrm{HT}_{1 \mathrm{~b}}$ as such does not modulate dorsal horn responses or primary afferent-evoked responses and is not involved in acute nociceptive behavior. ${ }^{34,45,56}$ Presynaptic $5-\mathrm{HT}_{2}$ receptor binding, and to some extent $5-\mathrm{HT}_{3}$ receptor binding, also mediate inhibition of primary afferent-evoked responses in a modest way. ${ }^{45,47}$

\section{Conclusions}

The proportion of serotonergic RVM-spinal cord-projecting neurons, as well as their axons in the spinal cord, rapidly increase during pre-weaning and mainly terminate in superficial laminae I and II. The descending serotonergic RVM projections to the spinal dorsal horn continue to facilitate nociceptive processing via $5-\mathrm{HT}_{2}$, $5-\mathrm{HT}_{3}$, and $5-\mathrm{HT}_{7}$ receptors from first postnatal week to weaning, corresponding with human term birth to early infancy. Spinal 5-HT inhibits the dorsal horn nociceptive network mainly via the $5-\mathrm{HT}_{1 \mathrm{a}}$ receptors during pre-weaning.

\section{SEROTONERGIC DESCENDING MODULATION OF NOCICEPTION FROM INFANCY (OR WEANING) UP TO ADULTHOOD (P21-ADULT)}

Anatomy of descending serotonergic RVM-spinal dorsal horn projections

The number of descending spinal cord projections originating from 5-HT-positive neurons in the RVM remains similar from weaning (P21) up to adulthood and account for approximately one-third of all 5-HT neurons projecting to the spinal cord. ${ }^{17,27} 5-$ HT axon terminals show highest innervation at the superficial laminae (rexed laminae I and II) and deeper dorsal horn lamina V where projection neurons reside in adulthood (see Fig. 2). ${ }^{17,28-30}$

\section{Functional implications of descending serotonergic RVM-spinal dorsal horn projections: effects on the nociceptive network}

Facilitation of the dorsal horn nociceptive network. In adulthood, the descending serotonergic system is functionally bimodal, producing either facilitation or inhibition (see "Inhibition of the dorsal horn nociceptive network") of the spinal nociceptive network by activating specific types of 5 - $\mathrm{HT}$ receptors. Stimulation of RVM at low intensities, optogenetic activation of tryptophan hydroxylase 2 neurons in the RVM, or depletion of descending serotonergic terminals have been shown to facilitate nociceptive behavior or processing in healthy adult rodents in some ${ }^{57-59}$ but not all studies ${ }^{17,60-62}$. At the same time, spinal 5 -HT does not facilitate acute mechanical and thermal nociception and facilitates spinal nociceptive signaling only in a minority of spinal neurons in adulthood under non pathological conditions ${ }^{63,64}$ through activation of the $5-\mathrm{HT}_{1 \mathrm{a}}{ }^{65-68} 5-\mathrm{HT}_{2 \mathrm{a} / \mathrm{c}}{ }^{69,70}$ and $5-\mathrm{HT}_{3}$ receptors ${ }^{68,71-78}$ (see Fig. $3 \mathrm{c}$ top). $5-\mathrm{HT}_{1 \mathrm{a}}$ receptors can facilitate nociceptive transmission by inhibiting GABAergic interneurons in the spinal cord. ${ }^{50,67}$ In addition, the spinal $5-\mathrm{HT}_{2 a}$ receptor can directly facilitate dorsal horn responses in the spinal cord. ${ }^{69} 5-\mathrm{HT}_{3}-$ mediated descending facilitation may occur through either modulation of supraspinal brain areas, ${ }^{79}$ via spinal microglia and subsequent astrocyte activation, ${ }^{80}$ via the modulation of longterm potentiation in NS projection neurons in the dorsal horn, ${ }^{71}$ or altering neuronal responses to natural stimuli in neurokinin-1expressing projection neurons. ${ }^{78}$ Activation of the $5-\mathrm{HT}_{3}$ receptor also consistently facilitates tactile processing in the deep dorsal horn in adulthood and this is similar to that noted during earlier developmental periods (see sections "Serotonergic descending modulation of nociception during the neonatal phase (P0-P7)" and "Serotonergic descending modulation of nociception during pre-weaning (P7-P21)"). ${ }^{17}$

Of note, in pathological pain states (including neuropathic or inflammatory pain models), the descending serotonergic system has been shown to produce predominant facilitation of spinal nociceptive processing that is mainly mediated via the $5-\mathrm{HT}_{3}$ receptors. For more information on the facilitatory role of $5-\mathrm{HT}$ in pathological pain states, the reader is referred to other reviews. ${ }^{81-83}$

Inhibition of the dorsal horn nociceptive network. The majority of studies show a bimodal role of descending serotonergic projections from the RVM on nociceptive processing in the spinal cord in healthy adult rodents, marking a shift in modulation from the facilitation observed throughout early development (see sections "Serotonergic descending modulation of nociception during the neonatal phase (P0-P7)" and "Serotonergic descending modulation of nociception during pre-weaning (P7-P21)") to bimodal control in adulthood. ${ }^{17,59,61}$ Indeed, RVM stimulation-induced antinociception can be abolished by spinal non-selective serotonergic antagonists. ${ }^{84-86}$ In addition, this descending inhibition in adulthood is functionally selective for nociceptive but not for tactile spinal processing. ${ }^{17,32}$ Depletion of descending 5-HT projections does not affect acute mechanical and thermal sensitivity ${ }^{60,61,87}$ but abolishes RVM stimulation-induced inhibition, ${ }^{61}$ where descending serotonergic projections are part of the spinal-bulbo-spinal feedback loop modulating spinal nociception in adulthood. Electrical stimulation of the RVM increases 5-HT and 5 -hydroxyindoleacetic acid efflux in the spinal cord in adulthood. ${ }^{88}$ The role of local spinal 5-HT on nociception in adulthood is mainly inhibitory. ${ }^{63,65,89-98} 5-\mathrm{HT}$ inhibits the dorsal horn nociceptive network in the adult rodent either directly via the $5-\mathrm{HT}_{1 \mathrm{a}} 63-65,91,92,99,100$ and $5-\mathrm{HT}_{1 \mathrm{~b}} 63,65,66,68,91,92,101$ receptors or indirectly via $5-\mathrm{HT}_{2 \mathrm{a}}{ }^{68,89,92,94}$ and $5-\mathrm{HT}_{3}{ }^{64,89,92,102-106}$ receptormediated activation of GABAergic neurotransmission that in turn inhibits the nociceptive network (see Fig. $3 \mathrm{c}$ bottom). Although the $5-\mathrm{HT}_{3}$ receptor affects naturally evoked (mechanical and thermal) stimuli, electrically evoked deep dorsal response were unaffected suggesting that the occurrence of $5-\mathrm{HT}_{3}$-mediated facilitation depends on the type of acute stimuli used. ${ }^{62,72,74,78,107}$ Up to now, the role of the spinal $5-\mathrm{HT}_{7}$ receptor in modulation of thermal or mechanical nociception-induced responses in the spinal nociceptive network is unclear. ${ }^{76,89,108-111} 5-\mathrm{HT}_{7}$-mediated effects are mostly studied in acute nociceptive behaviors, whereas $5-\mathrm{HT}_{7}$-mediated facilitation of dorsal horn responses is observed in earlier developmental periods (see section "Functional implications of descending serotonergic RVM-spinal dorsal horn projections: effects on the nociceptive network" and "Functional implications of descending serotonergic RVM-spinal dorsal horn projections: effects on the nociceptive network").

\section{Conclusions}

Serotonergic RVM-spinal cord projections terminate at the superficial laminae (rexed laminae I and II) and deeper dorsal 
horn lamina $\mathrm{V}$ in adulthood. Although the descending serotonergic system from the RVM is functionally bimodal, spinal 5-HT predominantly inhibits acute nociceptive behavior and spinal nociceptive processing in adulthood under non-pathological conditions, while it facilitates touch processing. Activation of 5$\mathrm{HT}_{1 \mathrm{a}}, 5-\mathrm{HT}_{2}$, and $5-\mathrm{HT}_{3}$ receptors result in both inhibition and facilitation of the spinal nociceptive network in healthy rodents. Activation of the $5-\mathrm{HT}_{1 \mathrm{~b}}$ results in inhibition of the spinal nociceptive network. Unlike earlier developmental periods, the role of the spinal $5-\mathrm{HT}_{7}$ receptor in acute spinal nociceptive processing in adulthood remains unclear.

\section{CLINICAL IMPLICATIONS OF THE POSTNATAL DEVELOPMENT OF DESCENDING RVM-SPINAL DORSAL HORN PROJECTIONS}

This review summarizes preclinical data on the development of descending serotonergic RVM-spinal dorsal horn projections and its role in nociception throughout the life span. In short, descending serotonergic projections from the RVM develop postnatally, where they sprout to the spinal dorsal horn in neonates, continue to increase their projections and axon innervation of the nociception specific laminae I, II, and V in the spinal cord in neonates and pre-weanling animals up to P21, and show highest innervation in adulthood (see Fig. 2). ${ }^{17,27-31}$ Functionally, the descending serotonergic RVM modulation of spinal nociception undergoes a major switch: from facilitatory during neonatal and pre-weaning phases to bimodal role in later phases (>P21; or post-weaning). ${ }^{16-18}$ Despite this switch in RVM serotonergic control of spinal nociception, inhibitory mechanisms mediated via the $5-\mathrm{HT}$ receptors are already present at an early age. This review also highlights the receptors involved in the functionality of the descending serotonergic modulation at various phases throughout the life span in rodents.

Although the majority of studies have been performed in laboratory rodents, clinical studies also suggest that descending modulation from the brainstem develops postnatally in human infants. ${ }^{6,112}$ The changing balance between NS brain activity and spinal reflexes suggests that, as cortical networks mature and thus NS activity emerges, descending inhibitory modulation is activated in human infants. ${ }^{6,112}$ Perhaps, postsynaptic facilitation mediated by $5-\mathrm{HT}$ in early life may promote the formation of a functional descending modulatory neuronal circuit via transformation of silent glutamatergic synapses to functional ones for more effective sensory transmission. ${ }^{36}$ Additionally, 5-HT-mediated facilitation modulates axon branching of descending projections in the spinal dorsal horn throughout development. ${ }^{13,114} \mathrm{~A}$ similar shift from facilitation to inhibition is seen in the developing spinal dorsal horn network in which GABAergic and glycinergic neurotransmission is involved. ${ }^{51,52,115}$ The exact mechanism by which descending serotonergic modulation switches from facilitation to bimodal control with postnatal age is not known due to the limited preclinical studies investigating the functionality of 5-HT receptor subtypes when the switch occurs (P21-P40), although endogenous opioidergic activity seems to play a role in the occurrence and/or timing of this switch. ${ }^{19}$ Excessive nociceptive input during early development, such as repeated noxious stimuli occurring frequently on a daily basis in newborns admitted to neonatal intensive care units and surgery in neonatal life, has been shown to augment the perception and/or processing of nociceptive stimuli ${ }^{16-120}$ and could consequently affect $5-\mathrm{HT}$ axon branching and the formation of a functional nociceptive neuronal network.

Several 5-HT receptors are involved in the functionality of this descending serotonergic modulation within the spinal nociceptive network of rodents (see Figs. 2 and 3). This information is relevant to clinical practice of preterm and term born infants, as it highlights a potential for serotonin-based pain treatment during this vulnerable period. Preclinical data show that $5-\mathrm{HT}_{1 \mathrm{a}}$ and
$5-\mathrm{HT}_{1 \mathrm{~b}}$ receptors inhibit the spinal nociceptive network throughout life, which can point toward a potential use of $5-\mathrm{HT}_{1 \mathrm{a}}$ or $5-\mathrm{H}_{1 \mathrm{~b}}$ receptor agonists for the treatment of pain during any developmental phase. As $5-\mathrm{HT}_{1 \mathrm{~b}}$-mediated inhibition of the spinal nociceptive network seems to be less robust during preweaning as compared to neonatal and adult phases, $5-\mathrm{HT}_{1 \mathrm{a}}$ receptor modulation could be better suitable for pain management in infants (between term birth and 1-2 years of age). ${ }^{34,45,56}$ Additionally, the $5-\mathrm{HT}_{3}$ receptor plays an important role in $5-\mathrm{HT}$ induced facilitation of the nociception during development (sections "Serotonergic descending modulation of nociception during the neonatal phase (P0-P7)", "Serotonergic descending modulation of nociception during pre-weaning (P7-P21)", and "Serotonergic descending modulation of nociception from infancy (or weaning) up to adulthood (P21-adult)"), and thus modulating this receptor is a promising additional therapeutic venue to treat pain in developing neonates and infants. In this context, it is important to note that the facilitation of touch signaling is also mediated via the $5-\mathrm{HT} 3$, and thus targeting this receptor may therefore impact the development of tactile processing. ${ }^{17}$ Finally, modulating the $5-\mathrm{HT}_{7}$ receptor throughout development, but not in adulthood, can be promising to treat pain in early life (sections "Serotonergic descending modulation of nociception during the neonatal phase (P0-P7)" and "Serotonergic descending modulation of nociception during pre-weaning (P7-P21)"). Agonists and antagonists of these receptors are currently available but are not part of the current clinical management of pain in neonates and infants. Daily clinical practice is mainly based on prescription of paracetamol, opioids, and non-pharmacological analgesia such as skin-to-skin care, non-nutritive sucking, and sucrose. ${ }^{121}$ Painful stimuli in early life, as well as the use of pharmacological treatment such as opioids, can lead to long-term alterations lasting into adulthood. ${ }^{11}$ Serotonin-mediated analgesia could aid the prevention of acute and long-term effects of neonatal pain, as it targets a part of the nociceptive system that is highly active at early ages. When testing any of these analgesics, side effects including anxiety and depression should be closely monitored due to the involvement of $5-\mathrm{HT}$ and the expression of $5-\mathrm{HT}$ receptors within the limbic system. ${ }^{122,123}$

Despite numerous years of research, several gaps in knowledge still exist. For example, the exact functionality of most serotonin receptors in an intact in vivo system during early age is not clear. Most studies, performed in developing rodents, assess receptor functionality in isolated spinal cord preparations or spinal slices, thereby removing the "serotonergic tone" from supraspinal areas including the RVM, which appears to be of vital importance. ${ }^{33-39,44-49,53-55}$ As descending serotonergic modulation plays an important role during any age, future preclinical studies should focus on this knowledge gap by investigating 5-HT receptor functioning in vivo rather than in vitro. Moreover, several drugs interacting with the 5-HT system, while studied in adulthood, should be investigated for specific postnatal age groups to assess functionality at different ages, thereby improving treatment of both procedural and surgical pain throughout neurodevelopment.

\section{CONCLUSIONS}

In conclusion, a rapid postnatal development of the descending serotonergic RVM-spinal dorsal horn projections is noted in rodents and this precedes a switch in descending modulation from facilitation before weaning to bimodal control of spinal nociceptive signaling in later life (childhood up to adulthood). More specifically, spinal 5-HT-mediated effects are functional at an early age, mediating inhibition of spinal nociception via the $5-\mathrm{HT}_{1 \mathrm{a}}, 5-\mathrm{HT}_{1 \mathrm{~b}}$, and $5-\mathrm{HT}_{2}$ receptors and facilitation mainly via the $5-\mathrm{HT}_{3}$ and $5-\mathrm{HT}_{7}$ receptors. At later phases, activation of all $5-\mathrm{HT}$ receptors, with exception of the $5-\mathrm{HT}_{7}$, might result in either 
facilitation or inhibition of acute spinal nociceptive signaling. Targeting the specific receptors in early developmental phases may help improve pain management in early life, preventing acute and long-term consequences of neonatal pain.

\section{REFERENCES}

1. Fitzgerald, M. \& Salter, M. W. The Neurobiology of Pain. In The Oxford Handbook of the Neurobiology of Pain. (ed. Wood, J. N.) 389-414 (Oxford University Press, 2020).

2. Fitzgerald, M. The development of nociceptive circuits. Nat. Rev. Neurosci. 6 , 507-520 (2005).

3. Fabrizi, L. et al. A shift in sensory processing that enables the developing human brain to discriminate touch from pain. Curr. Biol. 21, 1552-1558 (2011).

4. Green, G. et al. Behavioural discrimination of noxious stimuli in infants is dependent on brain maturation. Pain 160, 493-500 (2019).

5. Verriotis, M., Chang, P., Fitzgerald, M. \& Fabrizi, L. The development of the nociceptive brain. Neuroscience 338, 207-219 (2016).

6. Hartley, C. et al. Changing balance of spinal cord excitability and nociceptive brain activity in early human development. Curr. Biol. 26, 1998-2002 (2016).

7. Cornelissen, L. et al. Postnatal temporal, spatial and modality tuning of nociceptive cutaneous flexion reflexes in human infants. PLOS ONE 8, e76470 (2013).

8. Beggs, S., Torsney, C., Drew, L. J. \& Fitzgerald, M. The postnatal reorganization of primary afferent input and dorsal horn cell receptive fields in the rat spinal cord is an activity-dependent process. Eur. J. Neurosci. 16, 1249-1258 (2002).

9. Granmo, M., Petersson, P. \& Schouenborg, J. Action-based body maps in the spinal cord emerge from a transitory floating organization. J. Neurosci. 28, 5494-5503 (2008)

10. Waldenström, A., Thelin, J., Thimansson, E., Levinsson, A. \& Schouenborg, J. Developmental learning in a pain-related system: evidence for a cross-modality mechanism. J. Neurosci. 23, 7719-7725 (2003).

11. Van den Hoogen, N., Patijn, J., Tibboel, D. \& Joosten, E. Neonatal plasticity of the nociceptive system: mechanisms, effects, and treatment of repetitive painful procedures during NICU admittance. Curr. Pharm. Des. 23, 5902-5910 (2017).

12. Schwaller, F. \& Fitzgerald, M. The consequences of pain in early life: injuryinduced plasticity in developing pain pathways. Eur. J. Neurosci. 39, 344-352 (2014).

13. Walker, S. M. Long-term effects of neonatal pain. Semin. Fetal Neonatal Med. 24, 101005 (2019).

14. Millan, M. J. Descending control of pain. Prog. Neurobiol. 66, 355-474 (2002).

15. Battell, E. E., Lillywhite, A. \& Hathway, G. J. The changing role of descending control of spinal nociception over postnatal development. Curr. Opin. Physiol. 11, 93-96 (2019).

16. Schwaller, F., Kwok, C. \& Fitzgerald, M. Postnatal maturation of the spinal-bulbospinal loop: brainstem control of spinal nociception is independent of sensory input in neonatal rats. Pain 157, 677-686 (2016).

17. Schwaller, F., Kanellopoulos, A. \& Fitzgerald, M. The developmental emergence of differential brainstem serotonergic control of the sensory spinal cord. Sci. Rep. 7, 1-12 (2017).

18. Hathway, G., Koch, S., Low, L. \& Fitzgerald, M. The changing balance of brainstem-spinal cord modulation of pain processing over the first weeks of rat postnatal life. J. Physiol. 587, 2927-2935 (2009).

19. Hathway, G. J., Vega-Avelaira, D. \& Fitzgerald, M. A critical period in the supraspinal control of pain: opioid-dependent changes in brainstem rostroventral medulla function in preadolescence. Pain 153, 775-783 (2012).

20. Bravo, L., Llorca-Torralba, M., Berrocoso, E. \& Micó, J. A. Monoamines as drug targets in chronic pain: focusing on neuropathic pain. Front. Neurosci. 13, $1-25$ (2019).

21. Ohmura, Y. \& Kuniyoshi, Y. A translational model to determine rodent's age from human foetal age. Sci. Rep. 7, 1-8 (2017).

22. Romijn, H. J., Hofman, M. A. \& Gramsbergen, A. At what age is the developing cerebral cortex of the rat comparable to that of the full-term newborn human baby? Early Hum. Dev. 26, 61-67 (1991).

23. Workman, A. D., Charvet, C. J., Clancy, B., Darlington, R. B. \& Finlay, B. L. Modeling transformations of neurodevelopmental sequences across mammalian species. J. Neurosci. 33, 7368-7383 (2013).

24. Lidov, H. G. \& Molliver, M. E. Immunohistochemical study of the development of serotonergic neurons in the rat CNS. Brain Res. Bull. 9, 559-604 (1982).

25. Ballion, B., Branchereau, P., Chapron, J. \& Viala, D. Ontogeny of descending serotonergic innervation and evidence for intraspinal 5-HT neurons in the mouse spinal cord. Dev. Brain Res. 137, 81-88 (2002).

26. Deng, D. et al. Embryonic and postnatal development of the serotonergic raphe system and its target regions in 5-HT1a receptor deletion or overexpressing mouse mutants. Neuroscience 147, 388-402 (2007).
27. Tanaka, H. et al. Postnatal development of brainstem serotonin-containing neurons projecting to lumbar spinal cord in rats. Brain Dev. 28, 586-591 (2006).

28. Bregman, B. S. Development of serotonin immunoreactivity in the rat spinal cord and its plasticity after neonatal spinal cord lesions. Dev. Brain Res. 34, 245-263 (1987).

29. Xia, Y. et al. Serotonergic projections to lumbar levels and its plasticity following spinal cord injury. Neurosci. Lett. 649, 70-77 (2017).

30. Marlier, L., Poulat, P., Rajaofetra, N., Sandillon, F. \& Privat, A. Plasticity of the serotonergic innervation of the dorsal horn of the rat spinal cord following neonatal capsaicin treatment. J. Neurosci. Res. 31, 346-358 (1992).

31. Rajaofetra, N., Sandillon, F., Geffard, M. \& Privat, A. Pre- and post-natal ontogeny of serotonergic projections to the rat spinal cord. J. Neurosci. Res. 22, 305-321 (1989).

32. Koch, S. C. \& Fitzgerald, M. The selectivity of rostroventral medulla descending control of spinal sensory inputs shifts postnatally from a fibre to $\mathrm{C}$ fibre evoked activity. J. Physiol. 592, 1535-1544 (2014).

33. Garraway, S. M. \& Hochman, S. Serotonin increases the incidence of primary afferent-evoked long-term depression in rat deep dorsal horn neurons. J. Neurophysiol. 85, 1864-1872 (2001).

34. Garraway, S. M. \& Hochman, S. Pharmacological characterization of serotonin receptor subtypes modulating primary afferent input to deep dorsal horn neurons in the neonatal rat. Br. J. Pharmacol. 132, 1789-1798 (2001).

35. García-Ramírez, D. L., Calvo, J. R., Hochman, S. \& Quevedo, J. N. Serotonin, dopamine and noradrenaline adjust actions of myelinated afferents via modulation of presynaptic inhibition in the mouse spinal cord. PLOS ONE 9, e89999 (2014).

36. Li, P. \& Zhuo, M. Silent glutamatergic synapses and nociception in mammalian spinal cord. Nature 393, 695-698 (1998).

37. Iwasaki, T., Otsuguro, K.-I., Kobayashi, T., Ohta, T. \& Ito, S. Endogenously released 5-HT inhibits $A$ and $C$ fiber-evoked synaptic transmission in the rat spinal cord by the facilitation of GABA/glycine and 5-HT release via 5-HT2a and 5-HT3 receptors. Eur. J. Pharmacol. 702, 149-157 (2013).

38. Wallis, D. I., Wu, J. \& Wang, X. C. Is 5-hydroxytryptamine mediating descending inhibition in the neonatal rat spinal cord through different receptor subtypes? Eur. J. Pharmacol. 250, 371-377 (1993).

39. Hentall, I. \& Fields, H. Actions of opiates, substance $P$, and serotonin on the excitability of primary afferent terminals and observations on interneuronal activity in the neonatal rat's dorsal horn in vitro. Neuroscience 9, 521-528 (1983).

40. Lidov, H. G. \& Molliver, M. E. An immunohistochemical study of serotonin neuron development in the rat: ascending pathways and terminal fields. Brain Res. Bull. 8, 389-430 (1982).

41. Liu, Q. \& Wong-Riley, M. T. Postnatal changes in the expressions of serotonin $1 \mathrm{a}$, $1 \mathrm{~b}$, and $2 \mathrm{a}$ receptors in ten brain stem nuclei of the rat: implication for a sensitive period. Neuroscience 165, 61-78 (2010).

42. Chen, J. C., Turiak, G., Galler, J. \& Volicer, L. Postnatal changes of brain monoamine levels in prenatally malnourished and control rats. Int. J. Dev. Neurosci. 15, 257-263 (1997).

43. Fitzgerald, M. \& Koltzenburg, M. The functional development of descending inhibitory pathways in the dorsolateral funiculus of the newborn rat spinal cord. Dev. Brain Res. 24, 261-270 (1986).

44. Hori, Y., Endo, K. \& Takahashi, T. Long-lasting synaptic facilitation induced by serotonin in superficial dorsal horn neurones of the rat spinal cord. J. Physiol. 492, 867-876 (1996).

45. Hedo, G. \& Lopez-Garcia, J. 5-HT1b but not 5-HT6 or 5-HT7 receptors mediate depression of spinal nociceptive reflexes in vitro. Br. J. Pharmacol. 135, 935-942 (2002).

46. Saruhashi, Y., Young, W., Hassan, A. \& Park, R. Excitatory and inhibitory effects of serotonin on spinal axons. Neuroscience 61, 645-653 (1994).

47. Khasabov, S., Lopez-Garcia, J., Asghar, A. \& King, A. Modulation of afferentevoked neurotransmission by $5-\mathrm{HT} 3$ receptors in young rat dorsal horn neurones in vitro: a putative mechanism of $5-\mathrm{HT} 3$ induced anti-nociception. Br. J. Pharmacol. 127, 843-852 (1999).

48. Lopez-Garcia, J. \& King, A. Pre- and post-synaptic actions of 5-hydroxytryptamine in the rat lumbar dorsal horn in vitro: implications for somatosensory transmission. Eur. J. Neurosci. 8, 2188-2197 (1996).

49. Garraway, S. M. \& Hochman, S. Modulatory actions of serotonin, norepinephrine, dopamine, and acetylcholine in spinal cord deep dorsal horn neurons. J. Neurophysiol. 86, 2183-2194 (2001).

50. Wang, Y.-Y. et al. Expression patterns of 5-HT receptor subtypes $1 \mathrm{a}$ and $2 \mathrm{a}$ on gabaergic neurons within the spinal dorsal horn of Gad67-Gfp knock-in mice. J. Chem. Neuroanat. 38, 75-81 (2009).

51. Ben-Ari, Y. Excitatory actions of GABA during development: the nature of the nurture. Nat. Rev. Neurosci. 3, 728-739 (2002).

52. Baccei, M. L. \& Fitzgerald, M. Development of GABAergic and glycinergic transmission in the neonatal rat dorsal horn. J. Neurosci. 24, 4749-4757 (2004). 
53. Shay, B. L. \& Hochman, S. Serotonin alters multi-segmental convergence patterns in spinal cord deep dorsal horn and intermediate laminae neurons in an in vitro young rat preparation. Pain 95, 7-14 (2002).

54. Lopez-Garcia, J. \& King, A. A novel methodology for simultaneous assessment of the effects of 5-hydroxytryptamine on primary afferent polarisation and synaptic transmission in rat dorsal horn neurones in vitro. J. Neurosci. Methods 68, 1-6 (1996).

55. Worsley, M. A., Todd, A. J. \& King, A. E. Serotoninergic-mediated inhibition of substance $P$ sensitive deep dorsal horn neurons: a combined electrophysiological and morphological study in vitro. Exp. Brain Res. 160, 360-367 (2005).

56. Jeong, H. J., Mitchell, V. A. \& Vaughan, C. W. Role of 5-HT1 receptor subtypes in the modulation of pain and synaptic transmission in rat spinal superficial dorsal horn. Br. J. Pharmacol. 165, 1956-1965 (2012).

57. Cai, Y.-Q., Wang, W., Hou, Y.-Y. \& Pan, Z. Z. Optogenetic activation of brainstem serotonergic neurons induces persistent pain sensitization. Mol. Pain. 10, 1-9 (2014).

58. Rahman, W., Suzuki, R., Webber, M., Hunt, S. P. \& Dickenson, A. H. Depletion of endogenous spinal 5-HT attenuates the behavioural hypersensitivity to mechanical and cooling stimuli induced by spinal nerve ligation. Pain 123, 264-274 (2006).

59. Zhuo, M. \& Gebhart, G. Spinal serotonin receptors mediate descending facilitation of a nociceptive reflex from the nuclei reticularis gigantocellularis and gigantocellularis pars alpha in the rat. Brain Res. 550, 35-48 (1991).

60. Minor, B. G. et al. Noradrenergic and serotonergic involvement in brief shockinduced analgesia in rats. Behav. Neurosci. 102, 915-924 (1988)

61. Wei, F. et al. Molecular depletion of descending serotonin unmasks its novel facilitatory role in the development of persistent pain. J. Neurosci. 30, 8624-8636 (2010).

62. Kato, G. et al. Direct GABAergic and glycinergic inhibition of the substantia gelatinosa from the rostral ventromedial medulla revealed by in vivo patchclamp analysis in rats. J. Neurosci. 26, 1787-1794 (2006).

63. Xu, W., Qiu, X. \& Han, J. Serotonin receptor subtypes in spinal antinociception in the rat. J. Pharmacol. Exp. Ther. 269, 1182-1189 (1994).

64. Abe, K. et al. Responses to 5-HT in morphologically identified neurons in the rat substantia gelatinosa in vitro. Neuroscience 159, 316-324 (2009).

65. Ali, Z., Wu, G., Kozlov, A. \& Barasi, S. The actions of 5-HT1 agonists and antagonists on nociceptive processing in the rat spinal cord: results from behavioural and electrophysiological studies. Brain Res. 661, 83-90 (1994).

66. Alhaider, A. A. \& Wilcox, G. L. Differential roles of 5-hydroxytryptamine1a and 5hydroxytryptamine $1 \mathrm{~b}$ receptor subtypes in modulating spinal nociceptive transmission in mice. J. Pharmacol. Exp. Ther. 265, 378-385 (1993).

67. Bonnefont, J., Chapuy, E., Clottes, E., Alloui, A. \& Eschalier, A. Spinal 5-HT1a receptors differentially influence nociceptive processing according to the nature of the noxious stimulus in rats: effect of Way-100635 on the antinociceptive activities of paracetamol, venlafaxine and 5-HT. Pain 114, 482-490 (2005).

68. Crisp, T. et al. Analgesic effects of serotonin and receptor-selective serotonin agonists in the rat spinal cord. Gen. Pharmacol. 22, 247-251 (1991).

69. Rahman, W., Bannister, K., Bee, L. A. \& Dickenson, A. H. A pronociceptive role for the 5-HT2 receptor on spinal nociceptive transmission: an in vivo electrophysiological study in the rat. Brain Res. 1382, 29-36 (2011).

70. Srikiatkhachorn, A., Suwattanasophon, C., Ruangpattanatawee, U. \& PhansuwanPujito, P. 5-HT2a receptor activation and nitric oxide synthesis: a possible mechanism determining migraine attacks. Headache 42, 566-574 (2002).

71. Rygh, L. J. et al. Local and descending circuits regulate long-term potentiation and Zif268 expression in spinal neurons. Eur. J. Neurosci. 24, 761-772 (2006).

72. Suzuki, R., Rahman, W., Hunt, S. P. \& Dickenson, A. H. Descending facilitatory control of mechanically evoked responses is enhanced in deep dorsal horn neurones following peripheral nerve injury. Brain Res. 1019, 68-76 (2004).

73. Ali, Z., Wu, G., Kozlov, A. \& Barasi, S. The role of $5 \mathrm{HT} 3$ in nociceptive processing in the rat spinal cord: results from behavioural and electrophysiological studies. Neurosci. Lett. 208, 203-207 (1996).

74. Rahman, W. et al. Descending serotonergic facilitation and the antinociceptive effects of pregabalin in a rat model of osteoarthritic pain. Mol. Pain 5, 45 (2009).

75. Rahman, W., Suzuki, R., Rygh, L. J. \& Dickenson, A. H. Descending serotonergic facilitation mediated through rat spinal $5 \mathrm{HT} 3$ receptors is unaltered following Carrageenan inflammation. Neurosci. Lett. 361, 229-231 (2004).

76. Dogrul, A., Ossipov, M. H. \& Porreca, F. Differential mediation of descending pain facilitation and inhibition by spinal $5 \mathrm{HT}-3$ and $5 \mathrm{HT}-7$ receptors. Brain Res. 1280, 52-59 (2009).

77. Bannister, K. et al. Pregabalin suppresses spinal neuronal hyperexcitability and visceral hypersensitivity in the absence of peripheral pathophysiology. Anesthesiology 115, 144-152 (2011).
78. Suzuki, R., Morcuende, S., Webber, M., Hunt, S. P. \& Dickenson, A. H. Superficial Nk1-expressing neurons control spinal excitability through activation of descending pathways. Nat. Neurosci. 5, 1319-1326 (2002).

79. Huang, Z.-X. et al. Ondansetron attenuates bone cancer pain through the inhibition of Fos in the descending facilitation related nuclei. Int. J. Clin. Exp. Med. 11, 12197-12203 (2018).

80. Guo, W. et al. Spinal 5-HT3 receptors mediate descending facilitation and contribute to behavioral hypersensitivity via a reciprocal neuron-glial signaling cascade. Mol. Pain 10, 1-18 (2014).

81. Viguier, F., Michot, B., Hamon, M. \& Bourgoin, S. Multiple roles of serotonin in pain control mechanisms-implications of 5-HT7 and other 5-HT receptor types. Eur. J. Pharmacol. 716, 8-16 (2013).

82. Bardin, L. The complex role of serotonin and $5-\mathrm{HT}$ receptors in chronic pain. Behav. Pharmacol. 22, 390-404 (2011).

83. Bardoni, R. Serotonergic modulation of nociceptive circuits in spinal cord dorsal horn. Curr. Neuropharmacol. 17, 1133-1145 (2019).

84. Hammond, D. L. \& Yaksh, T. L. Antagonism of stimulation-produced antinociception by intrathecal administration of methysergide or phentolamine. Brain Res. 298, 329-337 (1984).

85. Satoh, M., Oku, R. \& Akaike, A. Analgesia produced by microinjection of Lglutamate into the rostral ventromedial bulbar nuclei of the rat and its inhibition by intrathecal A-adrenergic blocking agents. Brain Res. 261, 361-364 (1983).

86. Jensen, T. S. \& Yaksh, T. L. II. Examination of spinal monoamine receptors through which brainstem opiate-sensitive systems act in the rat. Brain Res. 363, 114-127 (1986).

87. Palm, F. et al. Reduced thermal hyperalgesia and enhanced peripheral nerve injury after hind paw inflammation in mice lacking the serotonin-transporter. Eur. J. Pain 12, 790-797 (2008).

88. Hammond, D., Tyce, G. \& Yaksh, T. Efflux of 5-hydroxytryptamine and noradrenaline into spinal cord superfusates during stimulation of the rat medulla. J. Physiol. 359, 151-162 (1985).

89. Xie, D.-J. et al. Identification of $5-\mathrm{HT}$ receptor subtypes enhancing inhibitory transmission in the rat spinal dorsal horn in vitro. Mol. Pain 8, 1-12 (2012).

90. Monroe, P. J. \& Smith, D. J. Demonstration of an autoreceptor modulating the release of $[3 \mathrm{H}]$ 5-hydroxytryptamine from a synaptosomal-rich spinal cord tissue preparation. J. Neurochem. 45, 1886-1894 (1985).

91. Eide, P. K., Joly, N. M. \& Hole, K. The role of spinal cord 5-HT1a and 5-HT1b receptors in the modulation of a spinal nociceptive reflex. Brain Res. 536, 195-200 (1990).

92. Liu, F.-Y. et al. Roles of 5-hydroxytryptamine (5-HT) receptor subtypes in the inhibitory effects of $5-\mathrm{HT}$ on $\mathrm{C}$-fiber responses of spinal wide dynamic range neurons in rats. J. Pharmacol. Exp. Ther. 321, 1046-1053 (2007).

93. Lu, Y. \& Perl, E. R. Selective action of noradrenaline and serotonin on neurones of the spinal superficial dorsal horn in the rat. J. Physiol. 582, 127-136 (2007).

94. Schmauss, C., Hammond, D. L., Ochi, J. W. \& Yaksh, T. L. Pharmacological antagonism of the antinociceptive effects of serotonin in the rat spinal cord. Eur. J. Pharmacol. 90, 349-357 (1983).

95. Bardin, L., Bardin, M., Lavarenne, J. \& Eschalier, A. Effect of intrathecal serotonin on nociception in rats: influence of the pain test used. Exp. Brain Res. 113, 81-87 (1997).

96. Hylden, J. L. \& Wilcox, G. L. Intrathecal serotonin in mice: analgesia and inhibition of a spinal action of substance P. Life Sci. 33, 789-795 (1983).

97. Yasaka, T., Tiong, S. Y., Hughes, D. I., Riddell, J. S. \& Todd, A. J. Populations of inhibitory and excitatory interneurons in lamina II of the adult rat spinal dorsal horn revealed by a combined electrophysiological and anatomical approach. Pain 151, 475-488 (2010).

98. Wang, G.-D. \& Zhuo, M. Synergistic enhancement of glutamate-mediated responses by serotonin and forskolin in adult mouse spinal dorsal horn neurons. J. Neurophysiol. 87, 732-739 (2002).

99. Nadeson, R. \& Goodchild, C. Antinociceptive role of 5-HT1a receptors in rat spinal cord. Br. J. Anaesth. 88, 679-684 (2002).

100. Colpaert, F. et al. Large-amplitude 5-HT1a receptor activation: a new mechanism of profound, central analgesia. Neuropharmacology 43, 945-958 (2002).

101. Gjerstad, J., Tjølsen, A. \& Hole, K. A dual effect of 5-HT1b receptor stimulation on nociceptive dorsal horn neurones in rats. Eur. J. Pharmacol. 335, 127-132 (1997).

102. Alhaider, A. A., Lei, S. Z. \& Wilcox, G. L. Spinal 5-HT3 receptor-mediated antinociception: possible release of GABA. J. Neurosci. 11, 1881-1888 (1991).

103. Kawamata, T., Omote, K., Toriyabe, M., Yamamoto, H. \& Namiki, A. The activation of 5 - HT3 receptors evokes GABA release in the spinal cord. Brain Res. 978, 250-255 (2003).

104. Glaum, S. R., Proudfit, H. K. \& Anderson, E. G. 5-HT3 receptors modulate spinal nociceptive reflexes. Brain Res. 510, 12-16 (1990).

105. Scott, J. A., Wood, M. \& Flood, P. The pronociceptive effect of ondansetron in the setting of P-glycoprotein inhibition. Anesth. Analg. 103, 742-746 (2006). 
106. Fukushima, T., Ohtsubo, T., Tsuda, M., Yanagawa, Y. \& Hori, Y. Facilitatory actions of serotonin type 3 receptors on gabaergic inhibitory synaptic transmission in the spinal superficial dorsal horn. J. Neurophysiol. 102, 1459-1471 (2009).

107. Green, G. M., Scarth, J. \& Dickenson, A. An excitatory role for 5-HT in spinal inflammatory nociceptive transmission; state-dependent actions via dorsal horn 5-HT3 receptors in the anaesthetized rat. Pain 89, 81-88 (2000).

108. Viguier, F. et al. Gaba, but not opioids, mediates the anti-hyperalgesic effects of 5-HT7 receptor activation in rats suffering from neuropathic pain. Neuropharmacology 63, 1093-1106 (2012).

109. Brenchat, A. et al. Pharmacological activation of 5-HT7 receptors reduces nerve injury-induced mechanical and thermal hypersensitivity. Pain 149, 483-494 (2010).

110. Brenchat, A., Ejarque, M., Zamanillo, D., Vela, J. M. \& Romero, L. Potentiation of morphine analgesia by adjuvant activation of 5-HT7 receptors. J. Pharmacol. Sci. 116, 388-391 (2011)

111. Brenchat, A., Zamanillo, D., Hamon, M., Romero, L. \& Vela, J. M. Role of peripheral versus spinal 5 -HT7 receptors in the modulation of pain undersensitizing conditions. Eur. J. Pain 16, 72-81 (2012).

112. Goksan, $\mathrm{S}$. et al. The influence of the descending pain modulatory system on infant pain-related brain activity. Elife 7, e37125 (2018).

113. Gibson, D. A. \& Ma, L. Developmental regulation of axon branching in the vertebrate nervous system. Development 138, 183-195 (2011).

114. Kalil, K. \& Dent, E. W. Branch management: mechanisms of axon branching in the developing vertebrate CNS. Nat. Rev. Neurosci. 15, 7-18 (2014).

115. Hathway, G. et al. A postnatal switch in gabaergic control of spinal cutaneous reflexes. Eur. J. Neurosci. 23, 112-118 (2006).

116. Beggs, S., Currie, G., Salter, M. W., Fitzgerald, M. \& Walker, S. M. Priming of adult pain responses by neonatal pain experience: maintenance by central neuroimmune activity. Brain 135, 404-417 (2012).

117. Walker, S. et al. Somatosensory function and pain in extremely preterm young adults from the UK Epicure cohort: sex-dependent differences and impact of neonatal surgery. Br. J. Anaesth. 121, 623-635 (2018).

118. Walker, S. M. et al. Long-term impact of neonatal intensive care and surgery on somatosensory perception in children born extremely preterm. Pain 141, 79-87 (2009).

119. van den Hoogen, N. J. et al. Repeated touch and needle-prick stimulation in the neonatal period increases the baseline mechanical sensitivity and postinjury hypersensitivity of adult spinal sensory neurons. Pain 159, 1166 (2018).

120. van den Hoogen, N., Patijn, J., Tibboel, D. \& Joosten, E. Repetitive noxious stimuli during early development affect acute and long-term mechanical sensitivity in rats. Pediatr. Res. 87, 26-31 (2020).

121. van den Hoogen, N. J. et al. Developmental neurobiology as a guide for pharmacological management of pain in neonates. Semin. Fetal Neonatal Med. 24, 1-7 (2019).

122. Hale, M. W., Shekhar, A. \& Lowry, C. A. Stress-related serotonergic systems: implications for symptomatology of anxiety and affective disorders. Cell. Mol. Neurobiol. 32, 695-708 (2012).

123. Hornung, J.-P. The neuroanatomy of the serotonergic system. In The Handbook of Behavioral Neuroscience. (eds Müller, C. P. \& Jacobs, B. L.) 51-64 (Elsevier, 2010).

124. Basbaum, A. I., Bautista, D. M., Scherrer, G. \& Julius, D. Cellular and molecular mechanisms of pain. Cell 139, 267-284 (2009).

125. Törk, I. Anatomy of the serotonergic system A. Ann. NY Acad. Sci. 600, 9-34 (1990).
126. Hannon, J. \& Hoyer, D. Molecular biology of 5-HT receptors. Behav. Brain Res. 195, 198-213 (2008).

\section{ACKNOWLEDGEMENTS}

A.R.d.K. is financially supported by the Pain Knowledge Center from Maastricht and an institutional grant from University Maastricht, School Mental Health and Neuroscience.

\section{AUTHOR CONTRIBUTIONS}

A.R.d.K., E.A.J.J., and N.J.v.d.H. designed and conceptualized the manuscript and contributed to the structure and content. A.R.d.K. drafted the manuscript and figures. All authors commented on previous versions of the manuscript, critically revised, and quality assessed the manuscript. All authors have read and approved the final version of the manuscript

\section{COMPETING INTERESTS}

The authors declare no competing interests.

\section{CONSENT STATEMENT}

No patient consent was required for this review article.

\section{ADDITIONAL INFORMATION}

Correspondence and requests for materials should be addressed to A.R.d.K.

Reprints and permission information is available at http://www.nature.com/ reprints

Publisher's note Springer Nature remains neutral with regard to jurisdictional claims in published maps and institutional affiliations.

(i) Open Access This article is licensed under a Creative Commons Attribution 4.0 International License, which permits use, sharing, adaptation, distribution and reproduction in any medium or format, as long as you give appropriate credit to the original author(s) and the source, provide a link to the Creative Commons license, and indicate if changes were made. The images or other third party material in this article are included in the article's Creative Commons license, unless indicated otherwise in a credit line to the material. If material is not included in the article's Creative Commons license and your intended use is not permitted by statutory regulation or exceeds the permitted use, you will need to obtain permission directly from the copyright holder. To view a copy of this license, visit http://creativecommons. org/licenses/by/4.0/.

(c) The Author(s), under exclusive licence to the International Pediatric Research Foundation, Inc 2021 